\title{
واقع تطبيق شفافية تقييم الأداء الوظيفي من وجهة نظر العاملين بالمعهد الصناعي الثانوي بمحافظة بدر
}

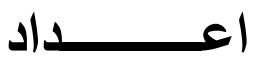 \\ أ. عبدالمعطي حميد حمان المطرفي \\ مدير المعهد الصناعي الثانوي بمحافظة بدر

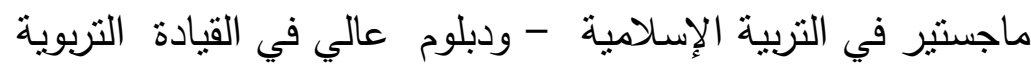

Doi:10.12816/0045866

مجلة الدراسات التربوية والانسانية ـ كلية التربية ـ جامعة دمنهور .

المجلد الثامن - العدد الرابع - الجزء (أ)- لسنة 7 ب 17 
واقع تطبيق شفافية تقييم الأداء الوظيفى من وجهة نظر العاملين بالمعهد الصناعى أ. عبدالمعى المطرفى 
واقع تطبيق شفافية تقييم الأداء الوظيفي من وجهة نظر العاملين بالمعهد الصناعي الثانوي بمحافظة بلر

أ. عبد المعطى المطرفى

\section{Doi:10.12816/0045866}

\section{ملخص البحث}

هدفت البحث الحالي إلى تحديد واقع تطبيق شفافية تقييم الأداء الوظيفي

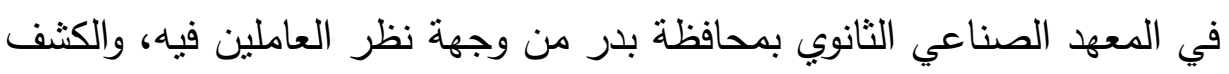
عن الفروق بين آراء عينة البحث حول تحديد واقع تطبيق شفافية تقييم الأداء الوظيفي في المعهد الصناعي الثانوي بمحافظة بدر من وجهة نظر العاملين فيه تعزى لمتغيرات البحث:(مسمى الوظيفة- عدد سنوات الخدمة)، واستخدمت

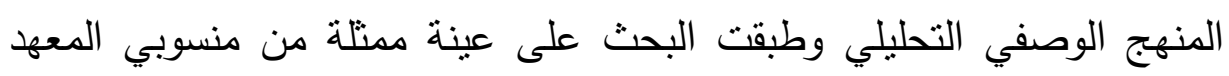

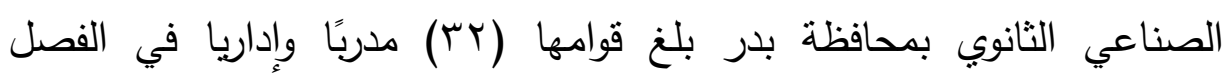

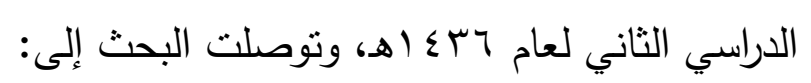

•أن واقع تطبيق شفافية تقييم الأداء الوظيفي في المعهد الصنام الصناعي الثنانوي بمحافظة بدر من وجهة نظر العاملين فيه كانت عالية، وكان أعلى فقرات الاستبانة على النحو التالي: يزود العاملين بنتائج ثقييم أدائهم ويتيح الرئيس المباشر للموظفين الاعتراض على نتائج تقييم أدائهم.

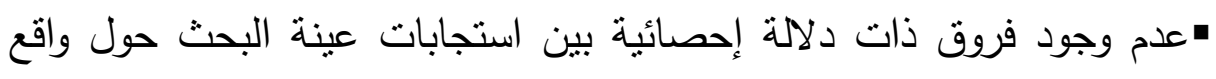

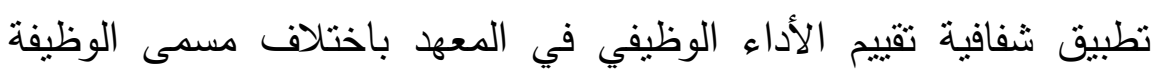

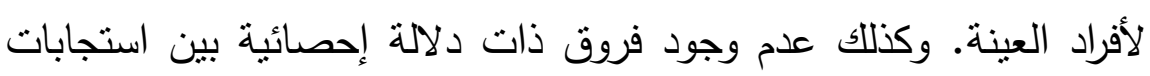

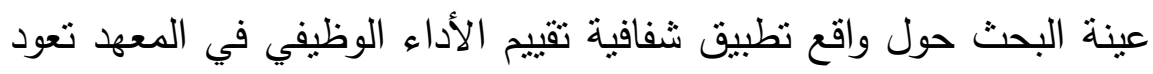
لاختلاف عدد سنوات خبرة أفراد العينة. 
واقع تطبيق شفافية تقييم الأداء الوظيفى من وجهة نظر العاملين بالمعهر الصناعى أ. عبدالمعى المطرفى

وفي ضوء النتائج ، من أهم توصيات البحث: ضرورة عمل خطة وبرنامج

لتقويم العاملين بشكل دوري (يومي-أسبوعي - شهري - فصلي) وإعطائهر

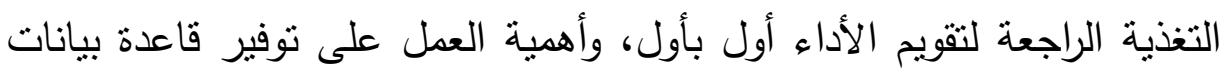

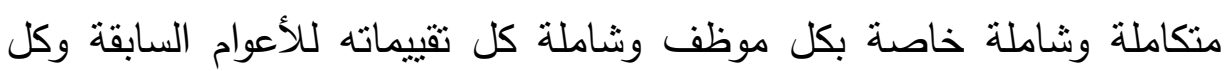
المهام الموكلة له.

الكلمات المفتاحية

شفافية تقييم الأداء - الأداء الوظيفي - المعهز الصناعي الثانوي. 


\section{مقدمة:}

يجب أن تحظى المؤسسات والمنظمات بتوفير نظام متكامل بضمن أداء

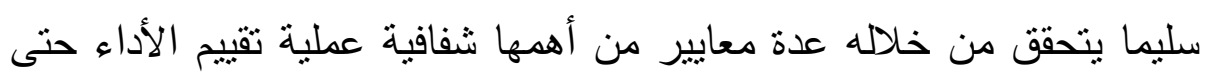

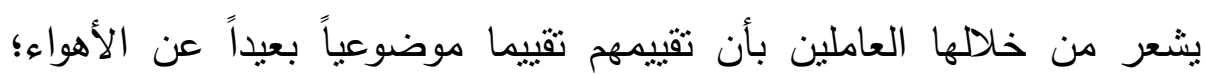
ويمكن أن تؤدى نتائج هذا التقييم الى إعادة النظر فى سياسات المؤسسة.

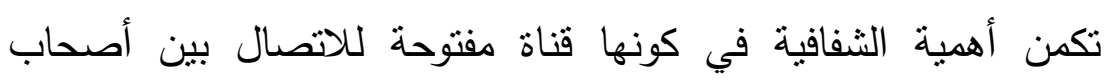

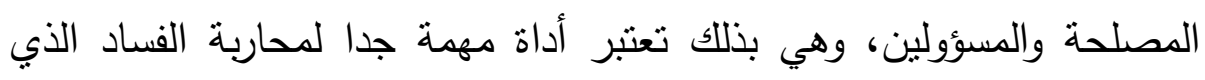
يستشري خاصة في الدول النامية، كما أن الثفافية وإن كانت مطلوبة في حياة

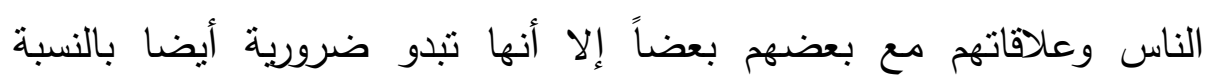

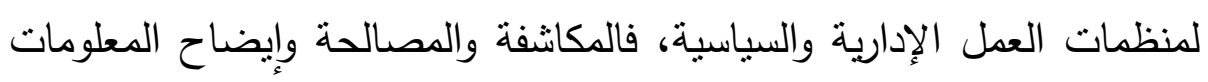

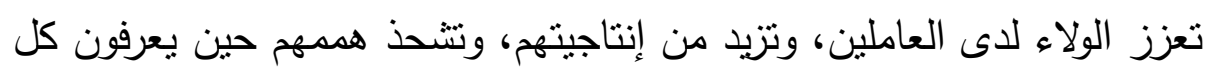

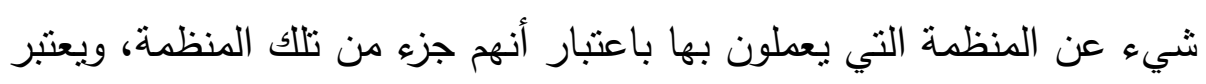

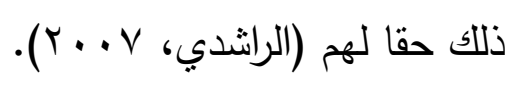

وتتحدد قدرة المنظمات في تحقبقها لأهدفها على مسنوى أداء العاملين

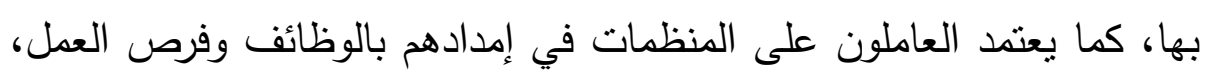

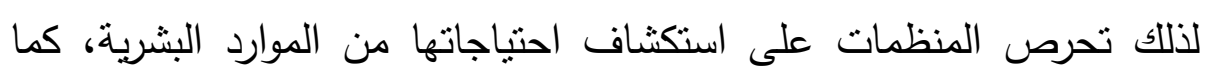
تعمل من أجل الحفاظ على فعاليتها ونموها، وفي مقابل ذللك يبحث الأفراد عن مواقع للعمل توفر لهم الأمن والتحدي وفرض التتمية الذاتية طوال حياتهرها، وفيل

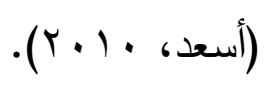

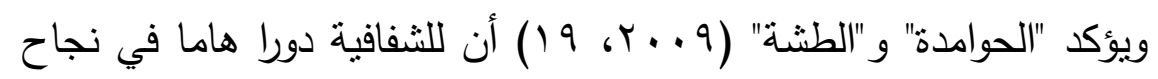

المؤسسات التربوية، ولكن مازالت ممارسات الثفافية غير واضحة في وزارات التربية والتعليم في الدول النامية، وأن هذه الوزارات تعاني من مشكلات إدارية وفنية. 
ونظراً لتوجه المعهز الصناعي الثانوي بمحافظة بدر لتطبيق الثفافية في

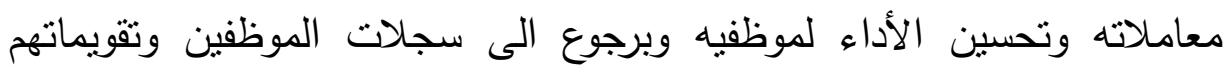
السابقة واجراء بعض المقابلات الثخصية معهم لتحقق من رضاء الموظفين وتطوير العمل رأت ادارة المعهد ضرورة إجراء دراسة خاصة بشفافية تقييم الأداء الوظيفي.

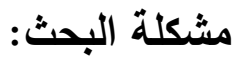

تتحدد مشكلة البحث في الحاجة للتحقق من واقع تطبيق شفافية تقييم الأداء الوظيفي في المعهد الصناعي الثانوي بمحافظة بدر، وذلك من خلد الإجابة على السؤالين التاليين: ا .ــا واقع تطبيـق شفافية تقيم الأداء الوظيفي في المعهد الصـناعي الثانوي بمحافظة بدر من وجهة نظر العاملين فيه؟

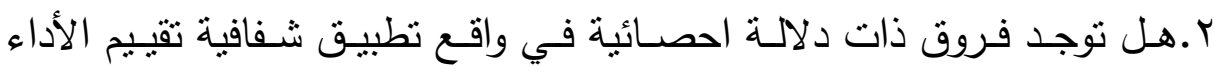
الوظيفي في المعهد الصناعي الثانوي بمحافظة بدر من وجهة نظر العاملين

$$
\begin{aligned}
& \text { فيه تعزى لمتغيرات البحث (مسمى الوظيفة- عدد سنوات الخدمة)؟ } \\
& \text { هدف البحث: يهدف البحث الحالي إلى: }
\end{aligned}
$$

• تحديد واقع تطبيق شفافية تقيم الأداء الوظيفي في المعهد الصناعي الثانوي بمحافظة بدر من وجهة نظر العاملين فيه. - الكثف عن الفروق بين آراء عينة البحث حول تحديد واقع تطبيق شفافية الأداء الوظيفي في المعهد الصناعي الثانوي بمحافظة بدر من وجهة نظر العاملين فيه تعزي لمتغيرات البحث.

أهمية البحث: بستمد البحث تستمد أهميته من حداثة موضوع شفافية تقييم الأداء

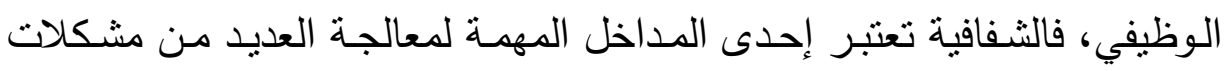
الإدارة الحكومية ، كما أن نتائجه يمكن أن تفيد في تطوير وتحسين عملية تقييم

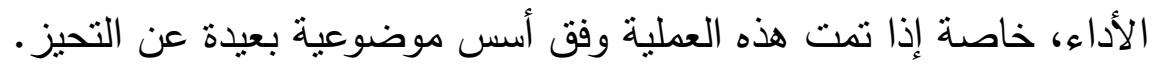


منهج البحث: استخدم البحث المنهج الوصفي التحليلي، فعلى صسيد البحث

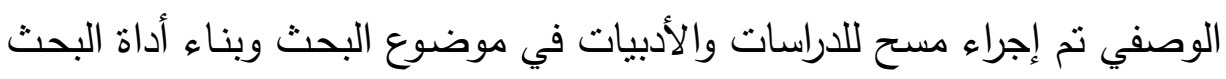

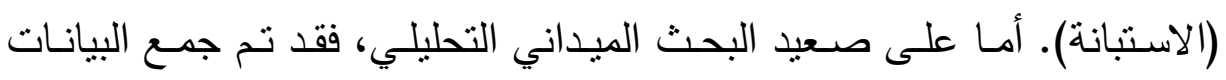

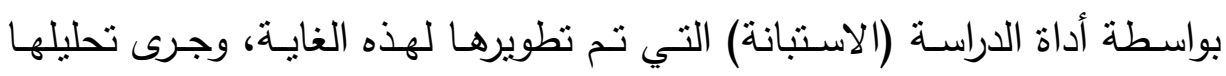
إحصائيا باستخدام الأساليب الإحصائية المناسبة.

مجتمع وعينة البحث: تكون مجتمع البحث من جميع موظفين المعهد من مدربين

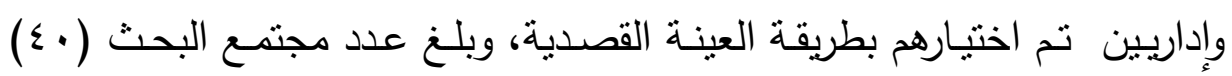

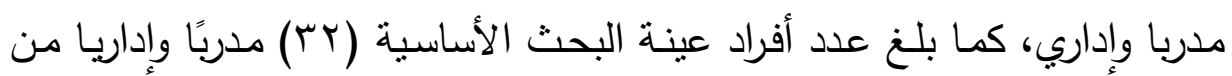

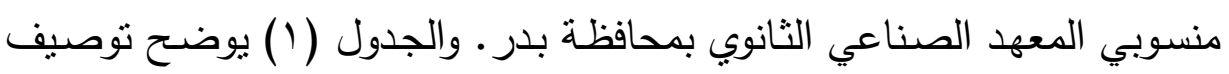
العينة حسب المؤهل والخبرة في مجال العمل.

الجدول ( 1 ) يوضح توصيف العينة حسب المؤهل والخبرة في مجال العمل

\begin{tabular}{|c|c|c|c|}
\hline المئوية & التكرار & الفئة & المتغير \\
\hline $7 \Lambda_{6} \wedge$ & rr & مدرب & \multirow{2}{*}{ مسمى الو ظيفة } \\
\hline r r r & 1. & إداري & \\
\hline$r_{1, q}$ & $v$ & أقل من ه سنو ات & \multirow{3}{*}{ الخبرة في مجال } \\
\hline$\Delta q, \varepsilon$ & 19 & خمس إلى اقل من عن & \\
\hline$\curlywedge \wedge, \wedge$ & 7 & عشر سنو ات فأكثر & \\
\hline$\% 1 \ldots$ & rr & \multicolumn{2}{|c|}{ المجموع } \\
\hline
\end{tabular}

أدوات البحثث: تمثلت أداة البحث في استبانة لقياس واقع تطبيق شفافية تقيهم الأداء الوظيفي في المعهد الصناعي الثانوي، وقد اشتملت على محورين، المحور

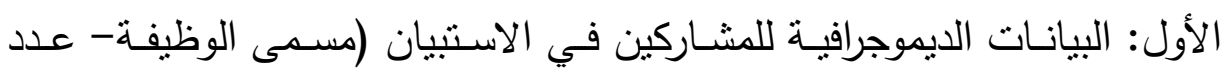

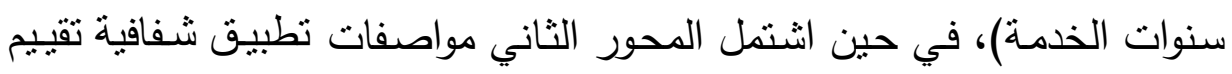
الأداء الوظيفي، وبلغ مجموع الفقرات خمسة عشر مفردة. 


\section{مصطلحات البحث:}

الأداء الـوظيفي: "عمليـة منظمـة لقياس وإصدار الأحكام وتقييم نتائج تحقيق أهداف أداء للموظف، وفق معايير الأداء والسلوك المتعلقة بالعمل، وكيفية أداء الموظف سابقًا وحاليًا، وكيف يمكن جعل أدائه لواجبات وظيفته بكفاءة أعلى في دواءي

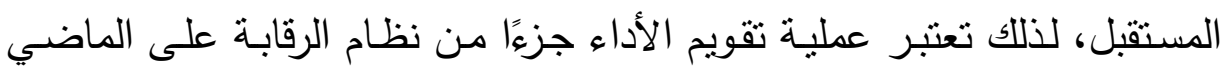

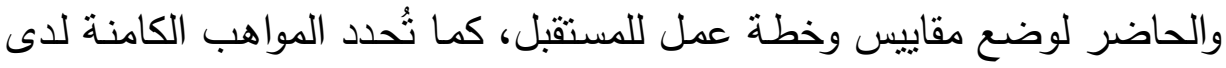

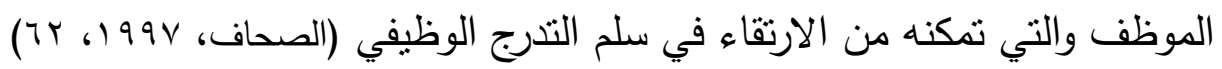
شفافية تقييم الأداء الوظيفي: مجموعة الخصائص التي يجب أن يتحلى بها

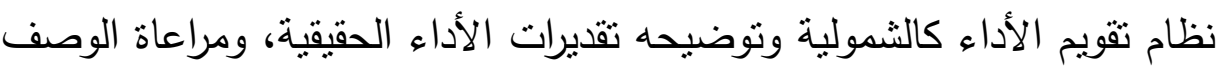
الوظيفي، والأهداف التي يراد تحقيقها من تطبيق نظام تقويم الأداء والتعرف على التى أوجه القوة والضعف وتطوير البرامج التدريبية لمعالجتها؛ وبالتالي تحسين الأداء للعاملين بشكل عام(الحوامدة، ؟ ـ . ؟ ). الاطار النظري والدراسات السابقة: تعتبر عملية تقويم الأداء الوظيفي من العمليات الإدارية الهامة، كونها

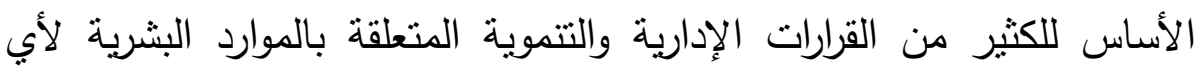

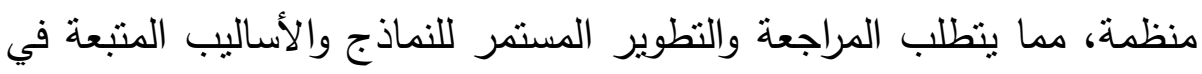
تقويم أداء العاملين لمواكبة مستجدات العصر التي تُحدِث الكثير من التغييرات على الوظائف ومتطلباتها واختصاصاتها (اليافعي، 7 ( • Y، • V V). كما تعتبر عملية تقييم الأداء الوظيفي من أهم العمليات ذات العلاقة في إدارة شئون العاملين في أية منظمة، لأن تقييم الأداء يسهم في مراجعة الأداء الهماء الهاء

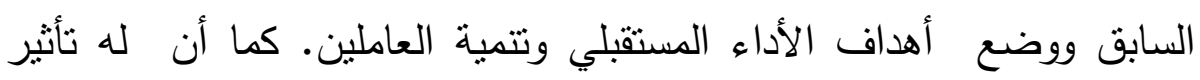
واضح في رضا العاملين ودافعيتهم للعمل، ويسهم كذلك في توفير المعلومات اللازمة واتخاذ الكثير من القرارات المتعلقة بالأفراد مثل العلاوات والتزقيات والتدريب والنقل وتخطيط الأداء وتحسين وتطوير معاييره، وبالرغم من كل ذلك بلك 
الا أن هذا الموضوع لم يلقى الاهتمام الكافي في الوطن العربي نتيجة لعدم إدرالك القائمين على هذه العملية بانعكاساتها على اتجاهات العاملين (الحوامدة،

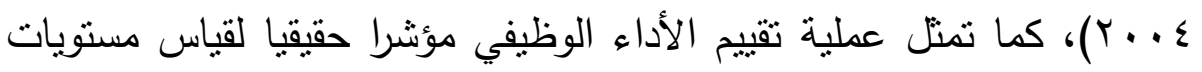

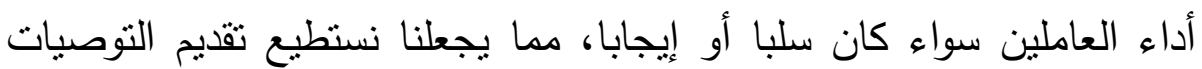
اللازمة، من أجل تلاشي-أو تقليل-هذه النواحي السلبية في أداء العاملين، وكيفية تتمية وتطوير -النواحي الإيجابية لهم. ويعد تقييم الأداء أحد مراحل

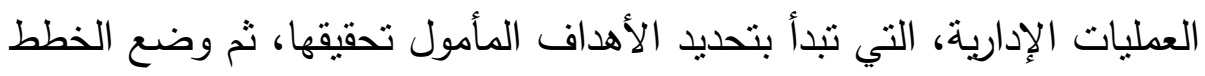

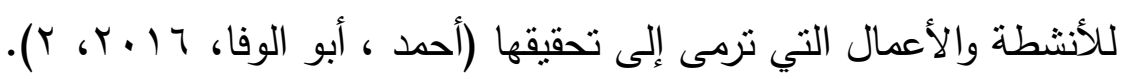
وأصبح التعامل مع شفافية تقييم الأداء من الأمور التي تأخذ حيزا كبيرا من اهتمامات المملكة العربية السعودية، وخاصة في ضوء المتغيرات العالمية المنسارعة في مجال مكافحة الفساد والثفافية، وما ينزتب عليها من انعكاسات على أداء المنظمات والمؤسسات المختلفة.

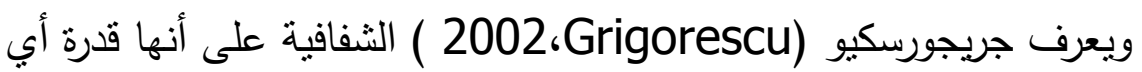
مواطن على الحصول على المعلومات الحكومية المحفوظة، حيث هناك العديد

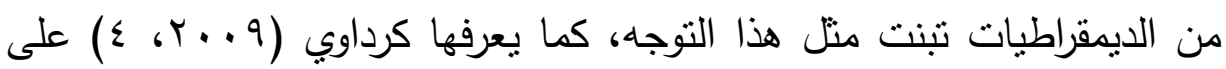

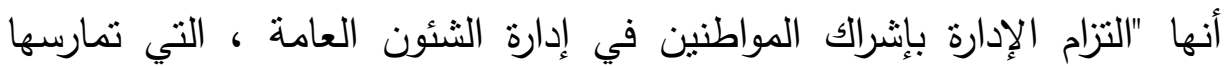

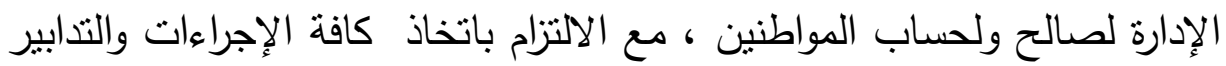
التي تضمن تزويد المواطنين بالبيانات والمعلومات الصادقة عن كافة خططها وأنشطتها وأعمالها ومشروعاتها وموازناتها ومداولاتها وإعلان الأسباب الواقعية والقانونية الدافعة لها". ويشير "الكايد" (r . . r) أن تطبيق مفهوم الثفافية بحاجة إلي حزمة من

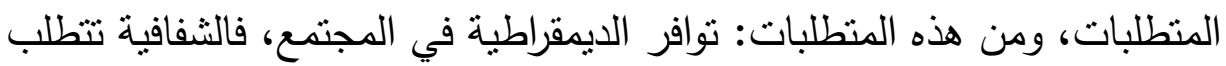
وجود ديمقراطية في الممارسات العملية، والممارسات الديمقراطية تضمن إمكانية الوصول إلي المعلومات من خلال قوانين لحرية المعلومات والحصول عليها من 
قبل المواطنين المعنيين أو من خلال نوافر الثفافية في القوانين والإجراءات، كما

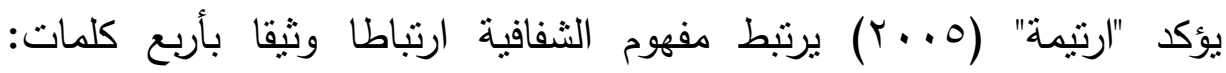
المصداقية والإفصاح والوضوح والمشاركة الثفافية تعني "وضوح التشريعات

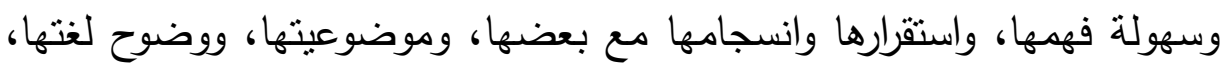

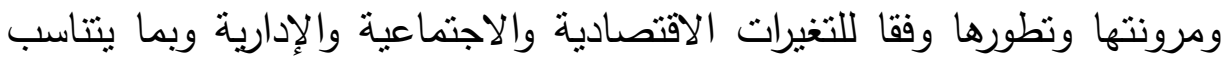

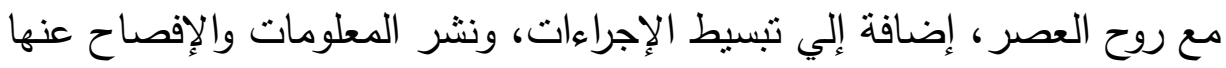

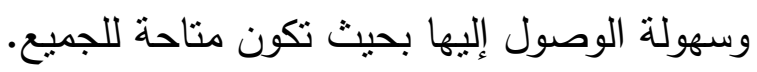
ومن أهم معوقات الثفافية التي اشتارت إليها نتائج دراسة "دعيبس"

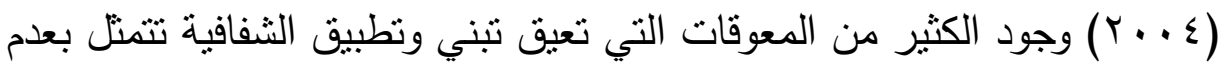

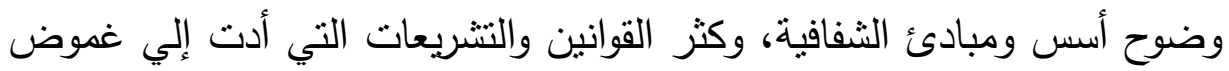
فكرة الثفافية، وبينت أن تطبيق الثفافية ليست بالأمر اليسير بسبب ضعن

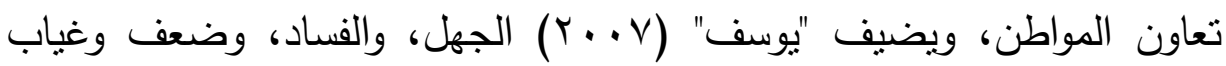
الاطار القانوني لحماية المواطن من غياب الثنفافية، بالإضافة لغياب الدور الفعال لمؤسسات المجتمع المدني وتعددت الدراسات السابقة التي حاولت نتاول الثفافية في تقييم الأداء الوظيفي، وفيما يلي عرض لبعض هذه الدات الداسات:

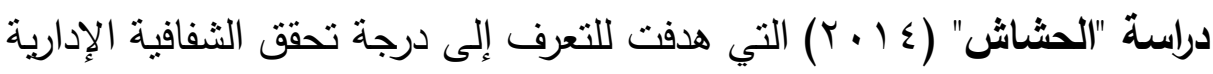
لاى مديري مديريات التربية والتعليم بمحافظات غزة وعلاقتها بدرجة أداء العاملين فيها، واتبعت الدراسة المنهج الوصفي التحليلي وأعد استبانتين كأداة للاراسة الأولى لتحديد درجة تحقق الثفافية الإدارية لدى مديري مديريات التربية والتعليم بمحافظات غزة والثانية لتحديد درجة أداء العاملين في مديريات التربية والتعليم بمحافظات غزة. وتكون مجتمع الدراسة من جميع رؤساء الأقسام والمشرفين التربويين العاملين في مديريات التربية والتعليم بمحافظات غزة والبالغ

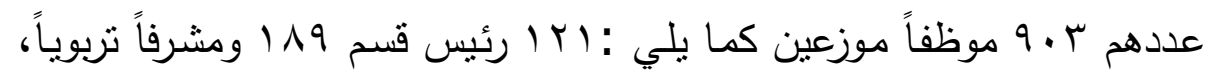

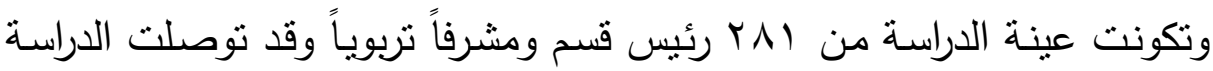
إلى النتائج التالية: أن درجة تحقق الثفافية الإدارية لدى مديري مديريات التربية

\section{Doi:10.12816/0045866}


والتعليم بمحافظات غزة كانت كبيرة، ولا توجد فروق ذات دلالة إحصائية بين

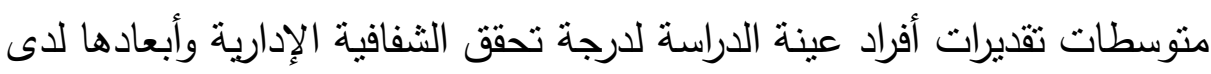
مديري مديريات التربية والتعليم بمحافظات غزة تعزى لمتغير (الجنس، المؤهل

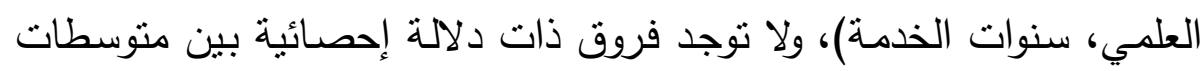

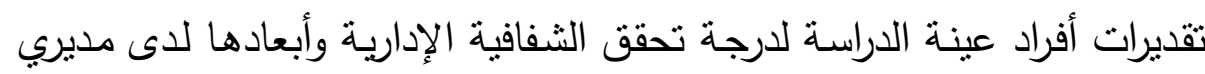

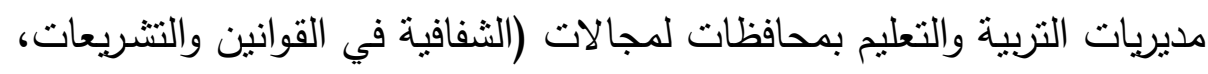

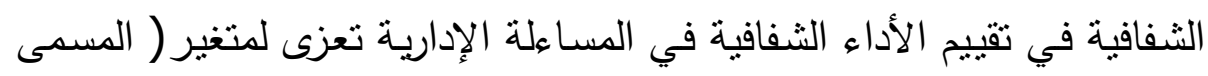
الوظيفي)

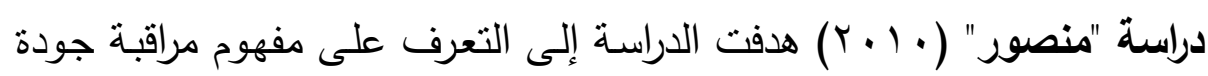
الأداء الإداري وآلياته وأنواعه بالمدارس الثنانوبة للبنات، بالإضـافة إلى إلى التعرف

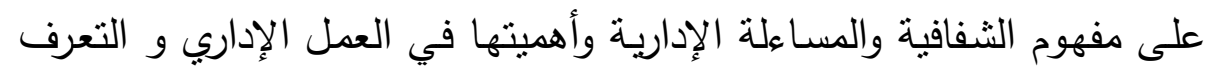

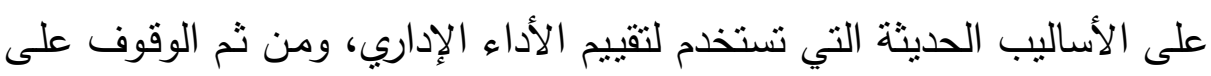

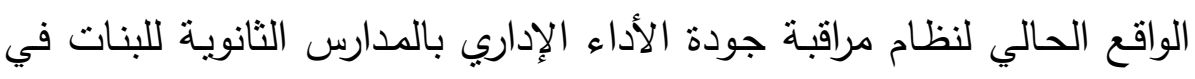

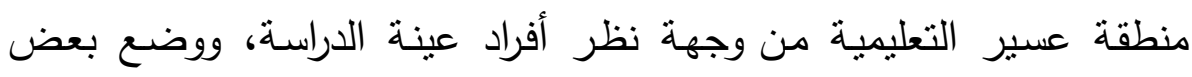

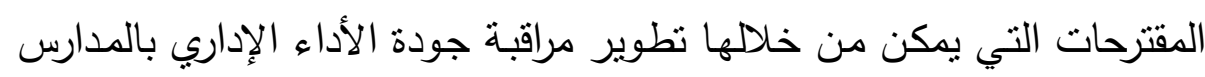

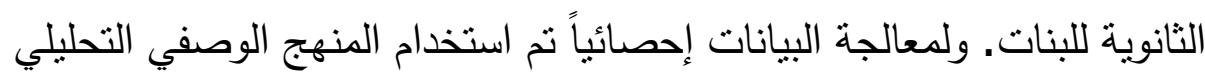

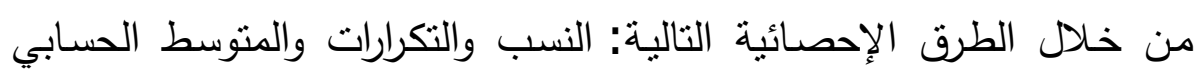
والانحراف المعياري واختبار ت للعينات المستقلة ـ وطُبقت الدراسة الميدانية باستخدام أداة الاستبانه على عينة الدراسة من مشرفات ومديرات ومعلمات

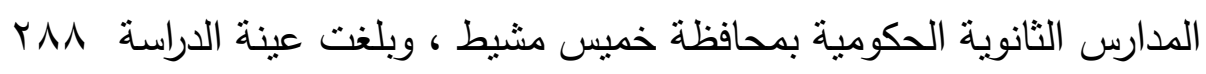
مشرفة ومديرة ومعلمة، وكان أبرز النتائج التي توصلت لها الدراسة على النحو

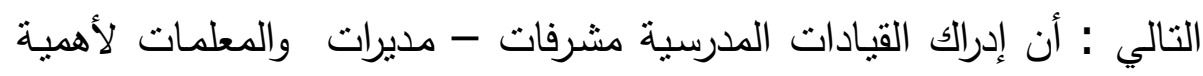

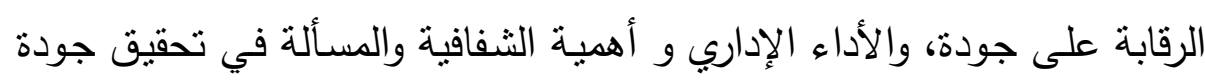

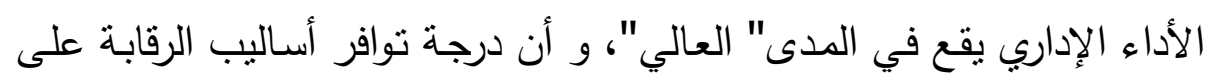
جودة الأداء الإداري بالمدارس الثانوية" متوسطة "، وأن المشرفات والمديرات 
والمعلمات يمارسن الثفافية والمسألة في الأداء الإداري داخل المدارس الثانوية بدرجة متوسطة.

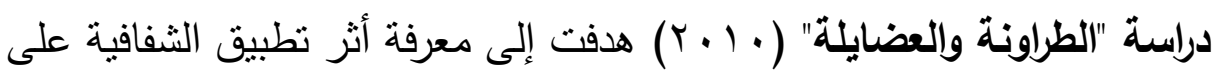

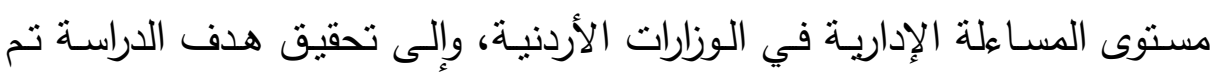

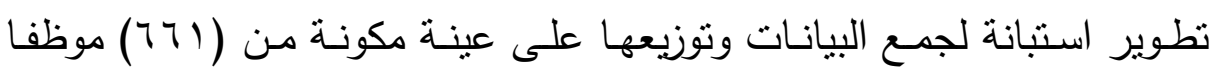

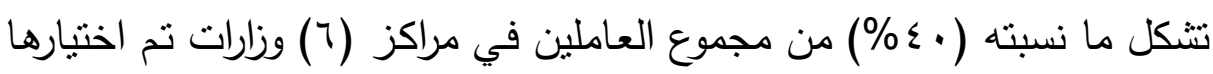

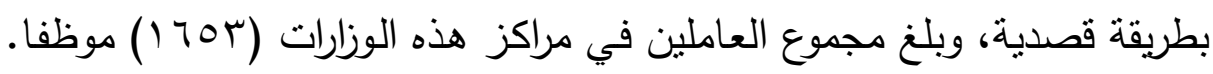

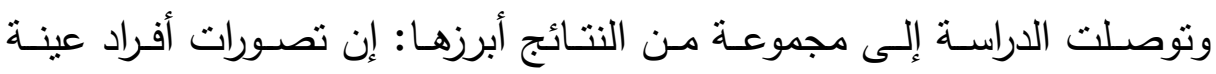
الدراسـة لكل من درجة تطبيق الثفافية ومستوى المساعلة الإداريـة في الوزارات

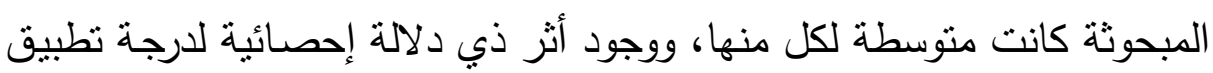
الثفافية بمجالاتها المختلفة مجتمعة ومنفردة على مستوى المساعلة الإدارية في الوزارات المبحوثة، كما أن شفافية القرارات هي أكثر مجالات الثفافية تأثثرا في

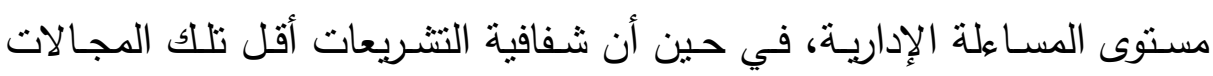

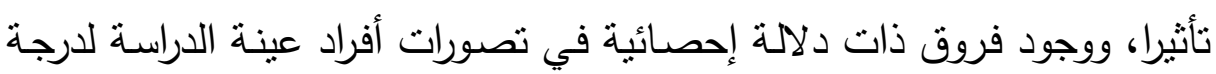

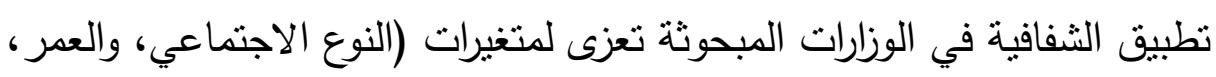

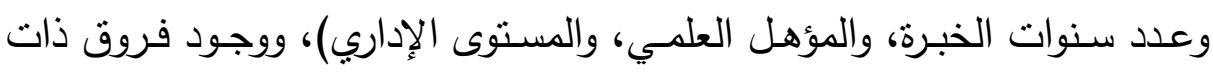

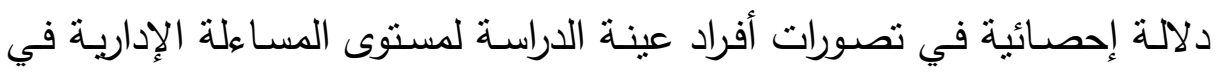

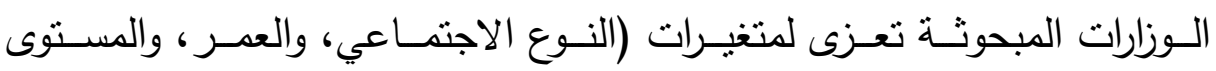
الإداري). دراسـة "الطشـة والحوامدة" (9 . . ؟ ) هدف هذا البحث إلي تعرف درجة الالنزام بالثفافية الإداريـة في وزارة التربية في دولة الكويت دن وجهة الهـة نظر الموظفين.

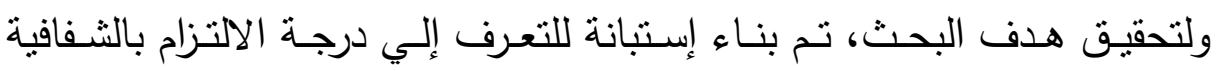

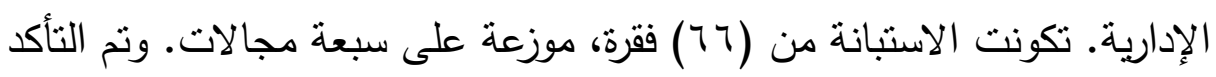
من صدقها بعرضها على مجموعة من المحكمين، ومن ثباتها بطريقة الاختبار

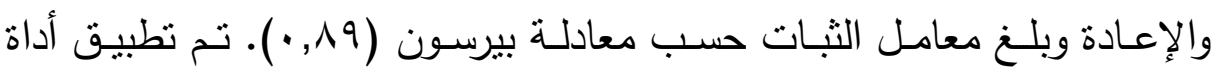




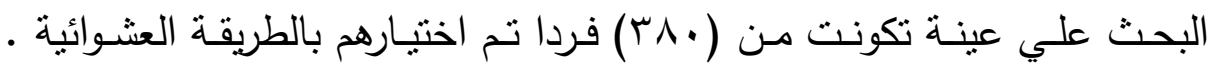

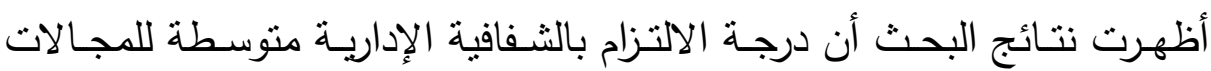
وللأداة ككل. وفي ضوء نتائج البحث يوصى بالعمل على رفع درجة الالنزام

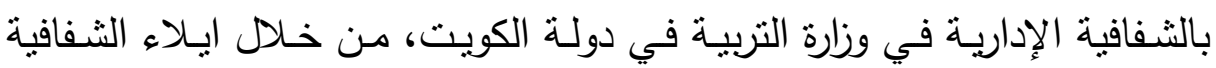
أهمية أكبر ، وتوضيحها للمواطنين والموظفين من خلال الأدلة والدورات والندوات

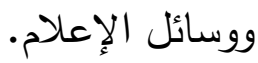
أجسرى "مارتـل" (Martell, 2007) دراسـة نوعيـة هدفت إلـى اختبـار الاستراتجيات والترتيبات الرسمية المستخدمة مـن قبل المسؤولين في الحكومـة فئس المحلية في البرازيل لتحسين مستوى الثفافية والمساءلة في الحكم المحلي. بينت

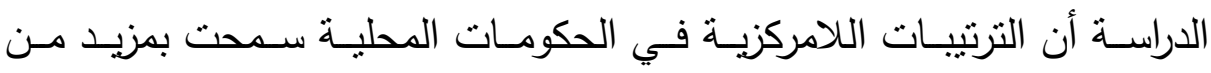
الاستجابة الحكوميـة للمطالب المحليـة للمواطنين على اختلاف أذواقهم وتغير المستهلكين، كما أن تلك الترتيبات اللامركزية عززت مستوى المشاركة السياسية وعملت على تقويـة الهياكل الديمقراطية، لكن القلق بثـأن اللامركزيـة هو إبراز

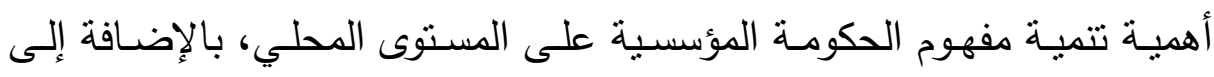

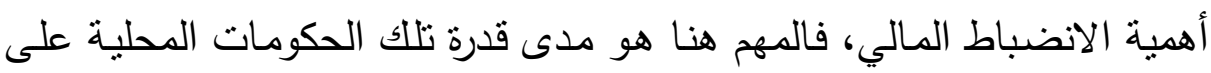

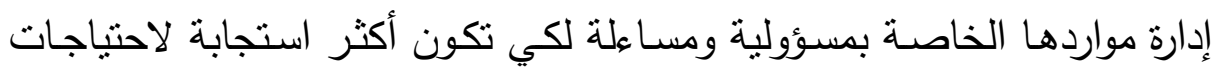
المواطنين المتزايدة في المستقبل، كما أظهرت نتائج الدراسة أهية الجهود الرامية

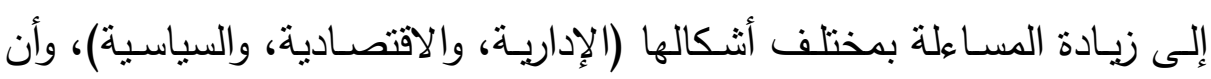
هذه الجهود يجب أن تكون متكاملة ومنتشابكة.

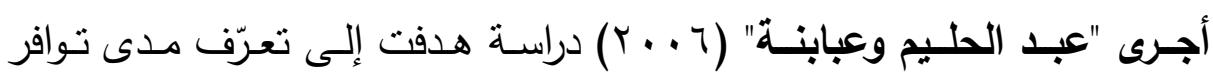
الثفافية والتفويض الإداري والبيئة الإبداعية والممارسة الإبداعية لتسع مؤسسات

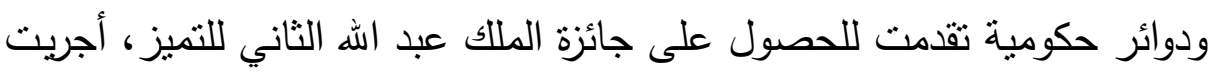
الدراسـة على عينة قصديه مكونـة من (و (ب) فردا شملت جميع أفراد القيادات

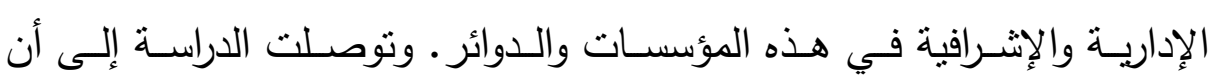

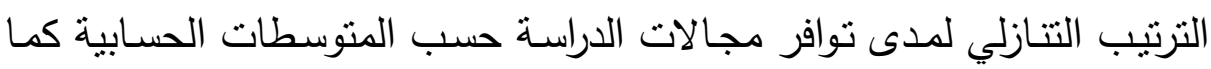


يأتي : الثفافية، ثم البيئة الإبداعية، يأتيه التقويض، وأخيرا الممارسة الإبداعية.

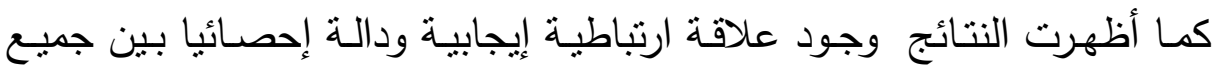

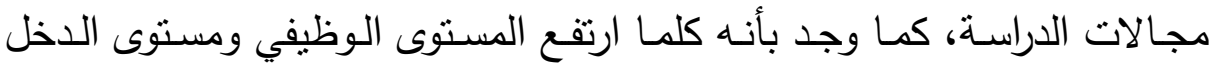

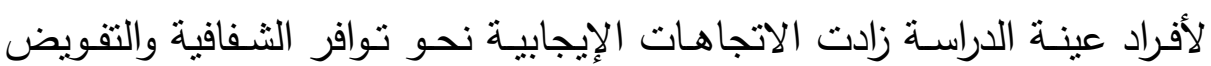

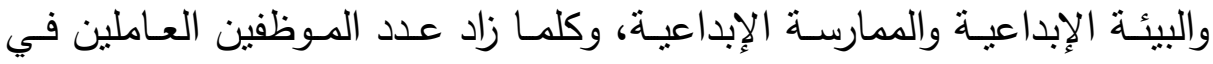

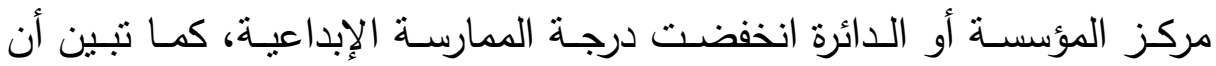

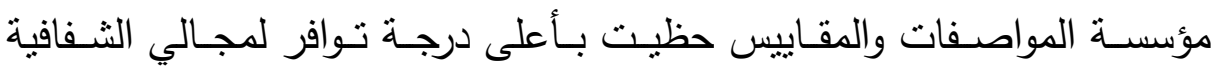
والتفويض، بينما كانتا الأقل توافرا في دائرة الأحوال المدنية.

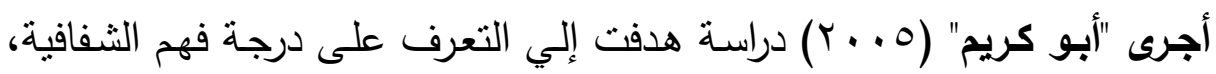

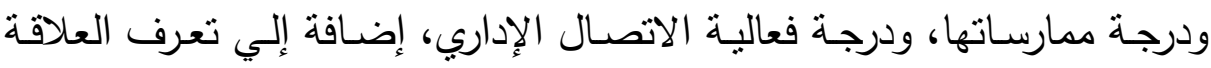

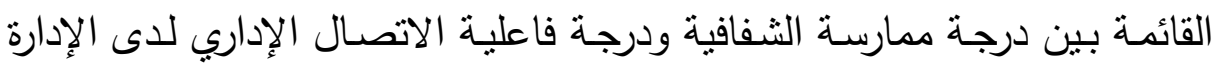

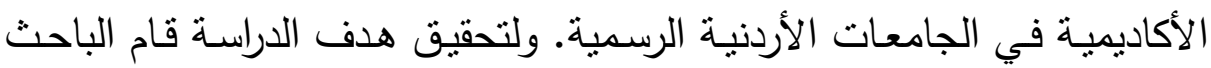

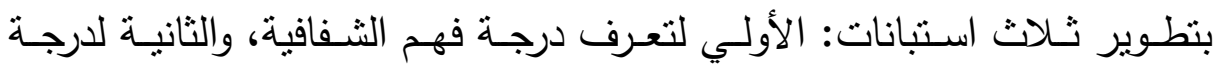
ممارسة الثفافية، والثالثة لدرجة فاعلية الاتصـال الإداري. وتكونت عينة الدراسة من (T • r) فردا من رئيس ونائب رئيس جامعة عميد ورئيس قسم أكاديمي. وبعد

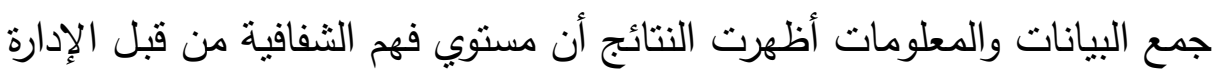

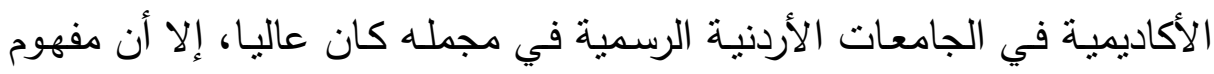

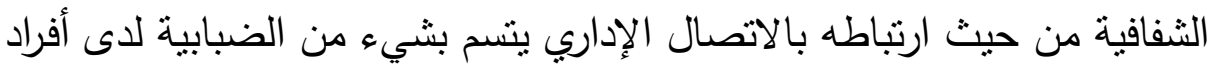

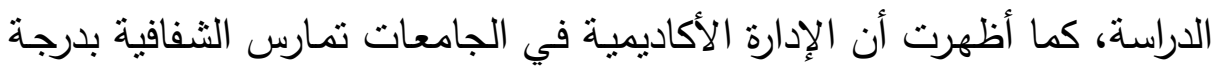

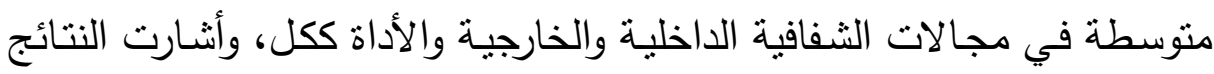

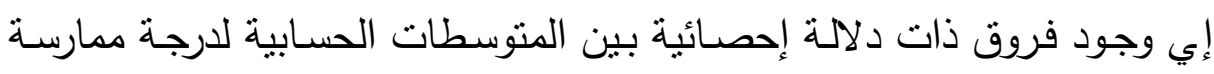

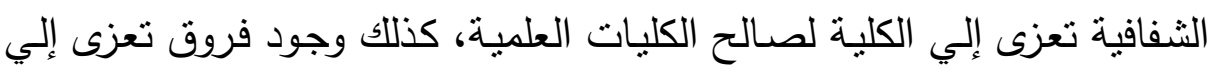

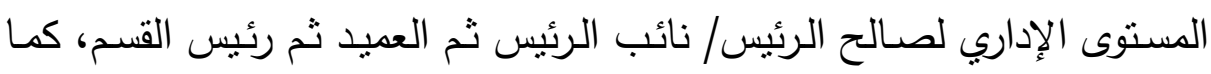

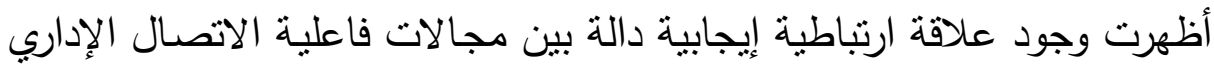

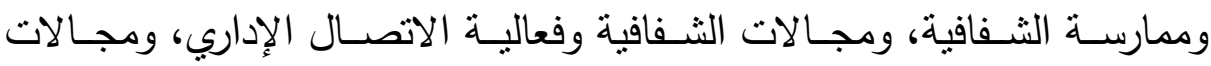


ممارسـة الثـفافية وفاعليـة الاتصـال الإداري، وبين درجـة ممارسـة الشفافية ككل ودرجة فاعلية الاتصال الإداري ككل.

وقامت "ارتيمة" (0 . . ب) بدراسة هدفت إلي التعرف على آراء العاملين في وزارة التربية والتعليم في ما يتعلق بواقع شفافية التقييم، وأهمية الثفافية في تقييم الأداء والمعوقات التي تواجه تحقيق شفافية التقييم والأساليب والآليات المقترحة لتطوير الثـفافية. تكـون مجتمـع الدراسـة مـن (Y r • I) موظفـا، وتـم جـع البيانـات مـن خلال استبانه تم تطوبرها لهذه الغايسة وتوزبعها على عينة الدراسـة التي تكونت مـن ( . . 7) موظف، وأظهرت الدراسـة أن اتجاهـات العـاملين في وزارة التربيـة والتعليم نحو مجالات الدراسة بشكل عام كانت جيدة، وخاصـة في مجال أهمية الثفافية في تحسين الأداء الذي حصل على درجة عالية، وأن من أكبر معوقات الثفافية نمط القيادة السائدة في الوزارة، الذي لا بعطي فرصة للمشاركة في اتخاذ القرارات، وأن الوزارة لا تعطي الدعم اللازم لترسيخ مبدأ الثفافية. قام "جريجورسكيو" (Grigorescu, 2002) بدراسة هدفت إلي تعرف السبب الـذي جعـل العديـــــن الـديمقراطيات الجديـدة تتبنـي بشـكل سـريع المؤسسـات المحلية التي تشجع الثفافية الحكومية، قام الباحث بفحص الدور المباشر الذي تقوم بـه المنظمات الدولية في مجال زيادة الثفافية المحلية. وأظهرت النتائج أن الآليات التي قامت من خلالها المنظمات الدولية اعتبرت كمؤثز على التطورات المحليـة في الديمقراطيات الحديثة، ولم تسـطع توضيح التطورات فيمـا يتعلـق بالثـفافية المحليـة الوطنيـة. وأخذت الدراسـة في الحسـاب عدة محددات محليـة تتعلق بعمليات الخصخصـة، والعلاقة بين السلطة التتفيذيـة والسلطة التشـربعية للحكومـة والمؤسسات الديمقراطية الأخرى الموجودة، وأوضـحت النتائج كيف أن هـذه العوامـل يمكن فقط أن تعطي تفسيرات جزئيـة عـن الزيـادة في الثـفافية المحلية، ووفرت النتائج تفسيراً بديلا كان بسبب الطلب المتزايد على المعلومات مـن قبـل المنظمـات الدوليـة، وتدفق المعلومـات المتزابـد مـن المنظمـات الدوليـة مباشرة إلي المجتمعات. 
وقد اتفقت الدراسات السابقة مع الدراسة الحالية في تقييم مدى تطبيق الثفافية من خلال أداة استبانة، كما استخدمت الدنهج الوصفي التحليليكي، والدراسات العربية سعت لتقييم مستوى الثنفافية بينما سعت الدراسات الأجنبية إما كائ

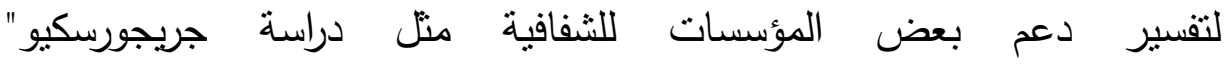
(Grigorescu, 2002)، أو نتاول كيفية اختيار الاستراتجيات والنرتييات

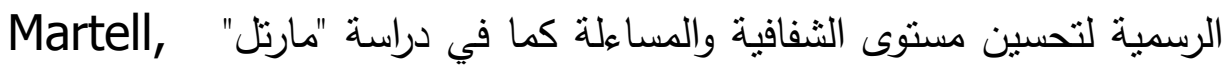

\section{منهج وإجراءات التجرية الميدانية:}

/ / بناء الاستبانة: تم تصميم الاستبانة على مقياس نمط ليكرت الخماسي Likert Scale الباحث بنطويرها وفق الخطوات التالية: الاطلاع على الأدب التزبوي والدراسات

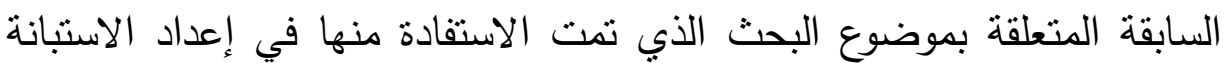

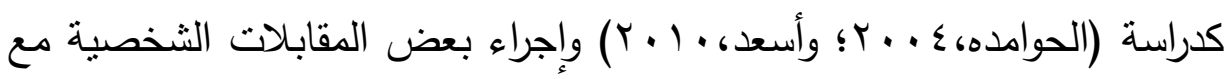

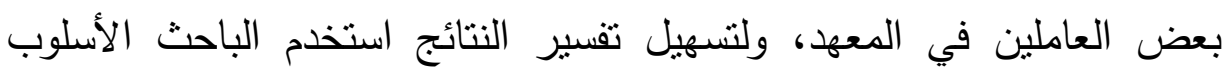

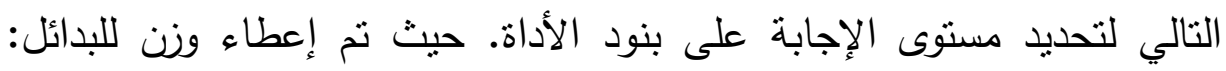

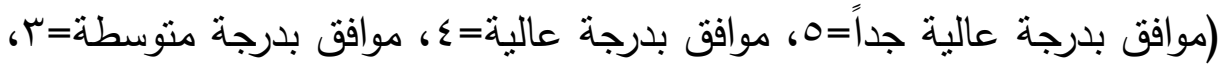

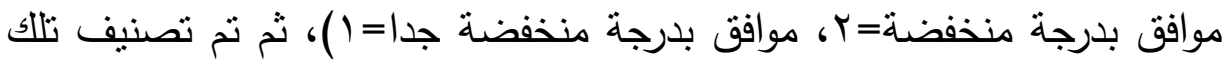
الإجابات إلى خمسة مستويات منساوية الددى من خلال المعادلة النالية: طول

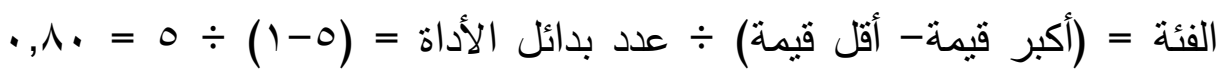
الموضحة بالجدول (r) النالي: النية

جدول (r) مستويات تصنيف الإجابات على الاستبانة

\begin{tabular}{|c|c|c|c|c|c|}
\hline منخفضقة بدرجةً & موافقي بلرجة & موافت بلرجة & موافى بلرجة & عوالية بدرجة & الوصف \\
\hline $\begin{array}{r}-1, \ldots \\
1, \wedge .\end{array}$ & $\begin{array}{r}-1, \wedge 1 \\
r, r . \\
\end{array}$ & $\begin{array}{r}-r, r) \\
r, \varepsilon .\end{array}$ & $\begin{array}{r}-r, \varepsilon 1 \\
\varepsilon, r .\end{array}$ & $\begin{array}{r}-\theta, \ldots \\
\varepsilon, r_{1}\end{array}$ & المتوسطات \\
\hline
\end{tabular}




\section{/ / التحقق من صدق وثبات الاستبانة:}

التحقق من صدق الأداة: ويقصد بصدق الأداة سلامة بنائها وقدرتها على

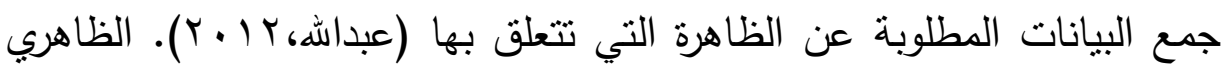
عن طريق عرض الاستبانة في صورتها الأولية على مجموعة من الخبراء لهنه والمحكمين والقيام بعمل التعديلات اللازمة وفق ما يروه مناسب، كما تم التحقق من صدق الاتساق الداخلي للاستبانة من خلال تطبيقه على عينة استطلاعية

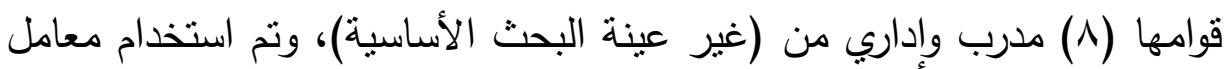
ارتباط سبيرمان لحساب مدى الإزتباط بين كل مفردة والدرجة الكلية للاستبانة، وقد أنشارات النتائج إلى وجود ارتباط دال احصائياً بين كل مفردة والدرجة الكلية

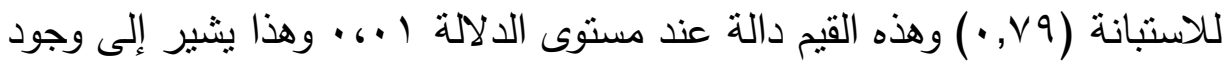

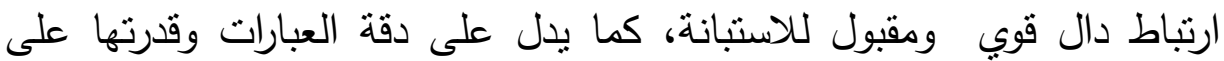
قياس ما وضعت من أجله.

التحقق من ثبات الأداة: ويقصد بثبات الأداة إعطاء نتائج مثقاربة أو نفس النتائج إذا طبقت أكثر من مرة في ظروف متماتلة (عباس، نوفل، العبسي، أبو عواد، Y ( † ). وللتأكد من ثبات أداة الاستبانة تم استخراج معامل ثبات الاستبانة لكل مجال من مجالات الاستبانة والمعامل الكلي باستخدام معادلة كرو نباخ

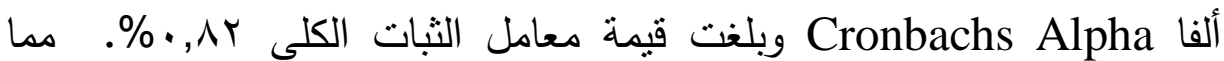
يجعل أداة البحث صالحة للاستخدام ومناسبة لغرض البحث العلمي. r/ توزيع الاستبانة على عينة البحث: توزيع الاستبانة ثم جمعها وتفريغ

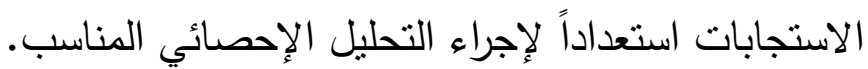




\section{تحليل نتائج البحث ومناقثتها:}

نتائج السؤال الأول: ما واقع تطبيق شفافية تقبيم الأداء الوظيفي في الدعرة

الصناعي الثانوي بدحافظة بلر من وجهة نظر العاملين فيه؟

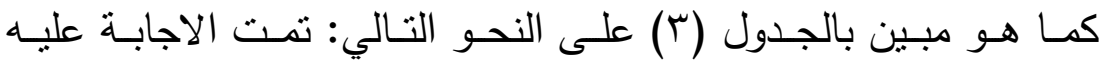
باسـتخدام الاحصــاء الوصـفي (المتوســات الحسـابية والاتحـراف المعيـاري) للوصـول لنتائج تقدير المدربين والمـوظفين لواقع تطبيـق شفافية تقيم الأداء الوظيفي في المعهد، ويوضـح جدول (ب) قيم المتوسط الحسـابي والانحراف لهـي

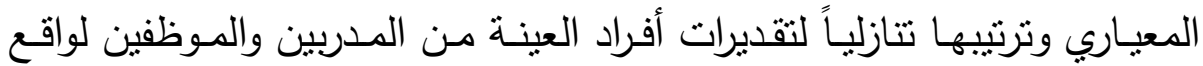
تطبيق شفافية تقييم الأداء الوظيفي في المعهد الصناعي الثانوي بمحافظة بدر من وجهة نظر العاملين فيه (ن=rr).

جدول (r) قيم المتوسط الحسابي والانحراف المعياري وترتيبها تنازلياً

\section{لتقديرات أفراد العينة}

\begin{tabular}{|c|c|c|c|c|c|}
\hline الرتبة & المستوى & الانحراف المعياري & المتوسط المسي & الفقرات & المفردة \\
\hline 1 & جاًاًة & 1,0 & $\varepsilon, \wedge$ & يزود العاملين بنتائج تقييم أدائهم. & 0 \\
\hline r & عالية جداً & $1, r$ & $\varepsilon, V$ & 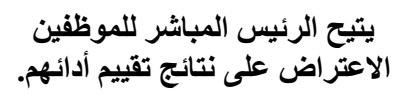 & $\wedge$ \\
\hline$r$ & عالية جداً & $1, r$ & $\varepsilon, 79$ & ترتبط بنود تقييم أداء الموظفين & v \\
\hline$\varepsilon$ & عالية جداً & $1, r$ & $\varepsilon, O r$ & يتم عمل تغذية راجعة لنتائج التقويم & 10 \\
\hline - & عالية & 1,1 & $\varepsilon, r$ & يقيم رئيسك بناءً على أسسة واضحة. & $r$ \\
\hline 7 & عالية & 1,1 & $\varepsilon, .9$ & يقوم رئيسك بعملية التقييم بنزاهة & $r$ \\
\hline v & عالية & $1, \cdot v$ & $r, q$ & يعكس نظام تقويم الأداء تقديرات & 9 \\
\hline
\end{tabular}


مجلة الدراسات التربوية والانسانية ـ كلية التربية ـ جامعة دمنهور . المجلد الثامن - العدد(؛)- الجزء (أ)- لسنة ؟ 1 ـ ب

\begin{tabular}{|c|c|c|c|c|c|}
\hline 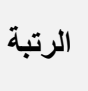 & المستوى & الاتحر اف المعياري & المستوسط & الفقرات & المفردة \\
\hline$\Lambda$ & عالية & $1, \cdot r$ & $r, \Lambda$ & يتيح مجلس المعهد في وضع معايير تقييه فزصة & Ir \\
\hline 9 & عالية & $1, \cdot r$ & $r, q$ & يغطي نظام تقويم الأداء جميع أبعاد & 1. \\
\hline 1. & عالية & $1, r$ & $r, 0$ & توجد آلية واضحة لاى المعهر & 7 \\
\hline 11 & متوسطة & $1, \cdot v$ & $r, r$ & تطبق الية تقييم الأداء بمصداقية & 1 \\
\hline Ir & متوسطة & $1, .0$ & $r, 1$ & للمقارنة بين المعهد سجلات معلوماتية المباء & ir \\
\hline ir & متوسطة & $1, \cdots v$ & $r, q$ & يتعامل نظام تقويم الأداء مع الوطيفي. & 11 \\
\hline $1 \varepsilon$ & منخفضة &.$\vee 9$ & $r, 0$ & بالمتطبات التِيمّاسية بأسس مرتبطة لإنجاز العمل. & $\varepsilon$ \\
\hline 10 & منخفضة & $1, r$ & $r, \varepsilon$ & منسوبيه بصورة مسئولين المعهد بتقويم خلائ العام. & $1 \leq$ \\
\hline & & & r.VTE & المتوسط الحسابي الكلي & \\
\hline
\end{tabular}

يبين جدول (r) أن المتوسط الحسـي الكلي لتقديرات أفراد العينـة مـن المدربين والموظفين لواقع تطبيق شفافية تقييم الأداء الوظيفي في المعهد. بلـغ

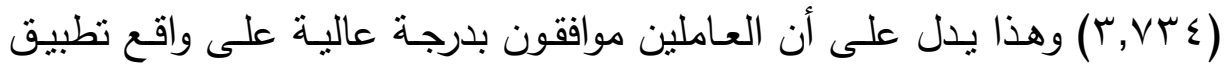
شفافية تقيبم الأداء الوظيفي في المعهد. وربمـا يعود السبب في ذلك إلى سعي الادارة والرؤساء في المعهد من ومدير ووكلاء ورؤساء أقسام على تحسين الأداء في العمل وتحقيق رضاء العاملين وعمل توازن بينهما، وأما فيما بتعلق بتقديرات المدربين والموظفين لواقع تطبيق شفافية تقييم الأداء الوظيفي في المعهد كما في جدول (r) أن المتوسط الحسـابي لتقديرات أفراد العينـة مـن المدربين والإداريبين 


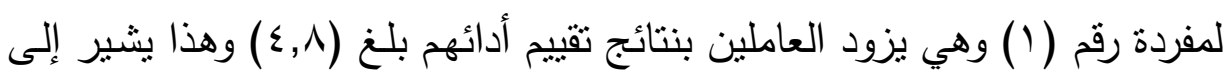

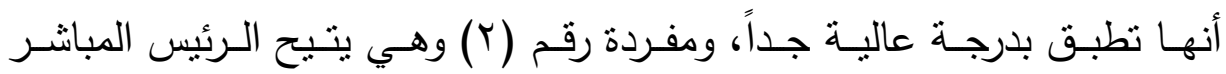

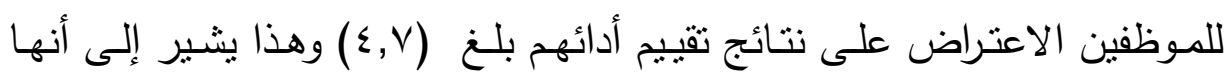
تطبق بدرجة عالية جداً، ومفردة رقم (r) وهي ترنبط بنود تقييم أداء الموظفين

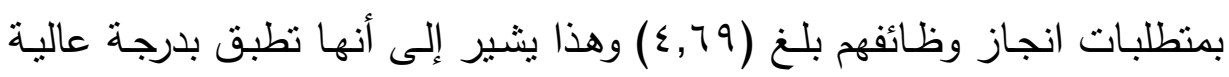

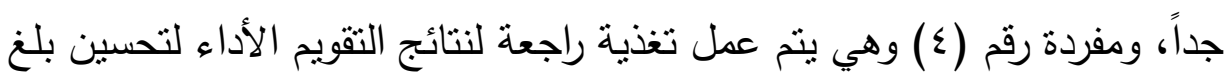

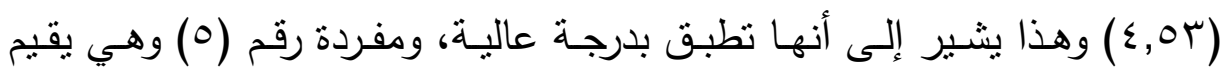

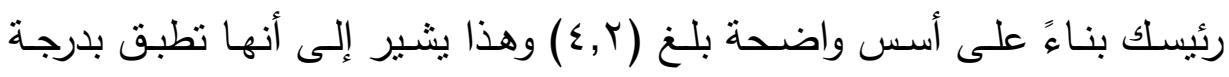
عاليـة، ومفردة رقم (1) (1)، وهي يـوفر المعهد سجلات معلوماتيـة للمقارنـة بين

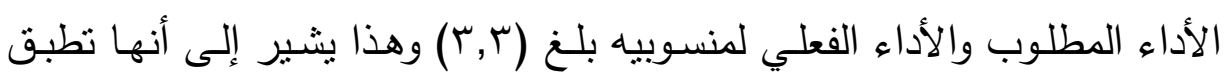

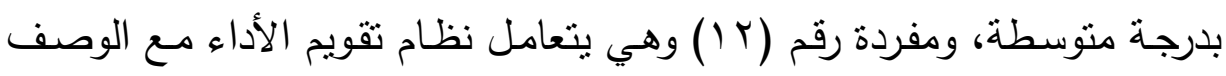

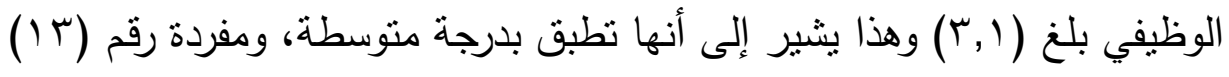

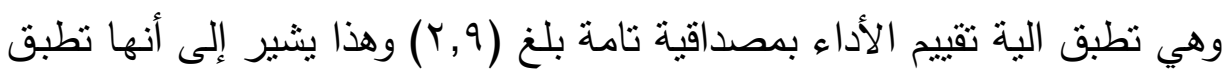
بدرجة متوسطة، ومفردة رقم (ع () وهي يتم التقيم بأسس مرتبطة بالمتطلبات

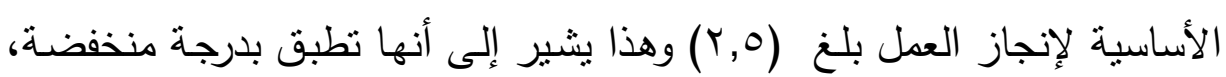
ومفردة رقم (10) وهي يقوم مسئولين المعهد بتقويم منسوبيه بصورة دورية خلال

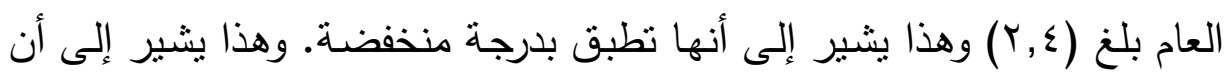

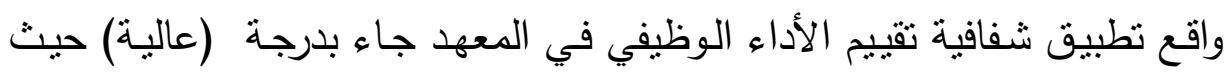

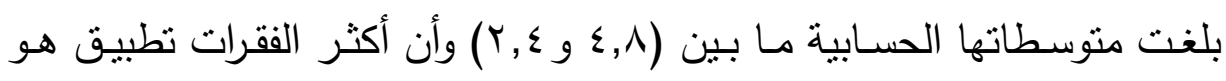

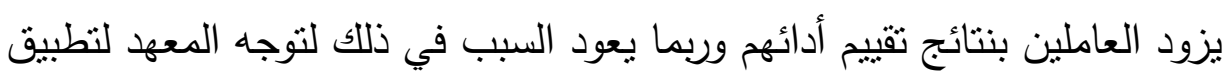

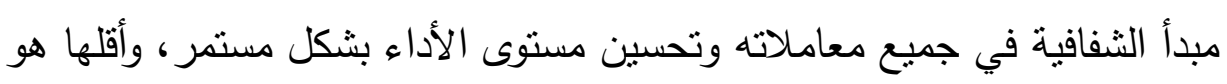

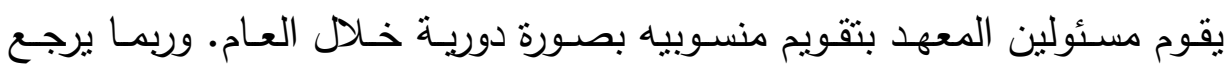
السبب في ذلك لوجود النظام التلني والذي يحتوي على ثلاثة فصول دراسية ويقيم

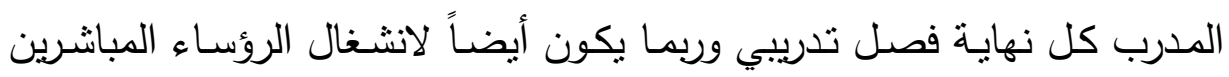
بتكليفات اخرى. 
أكدت النتائج السابقة أن العاملين بالمعهد موافقون بدرجة عالية على واقع

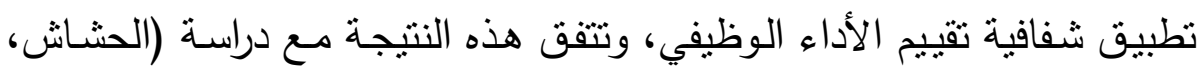

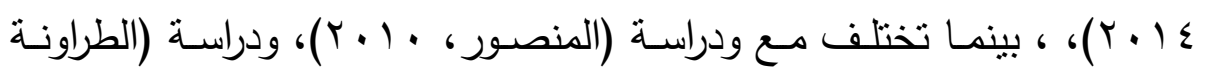

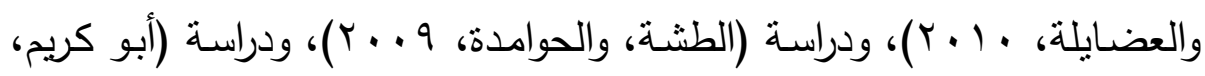

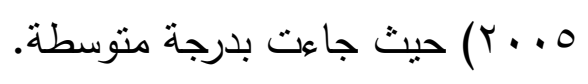

إجابة السؤال الثاني: هل توجد فروق ذات دلالة احصائية في واقع تطبيق

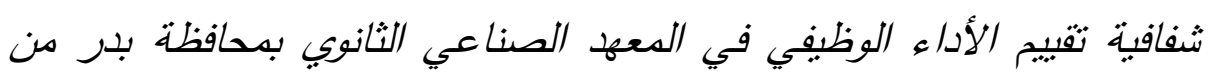

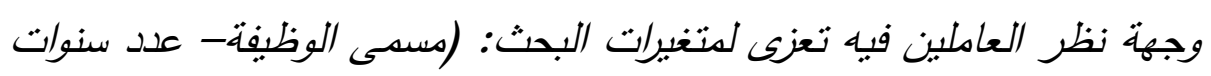

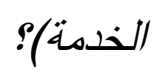

t test تمت الاجابة عليه باستخدام الاحصاء الاستذلالي (اختبار

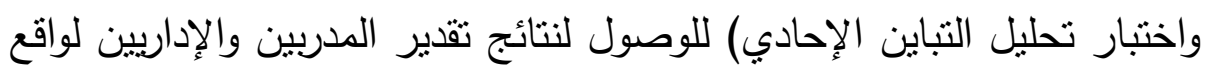

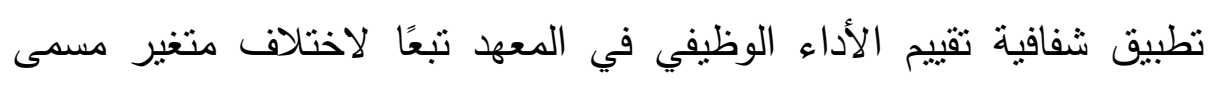
الوظيفة. وجدول التالي يوضح اختبار (ت) لدلالة الفروق في استجابات عينة

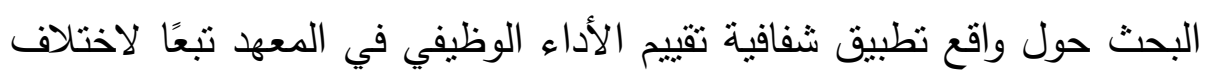
متغير مسمى الوظيفة. يبين جدول (ع) أن مستوى الدلالة للمجموع الكلي لتقديرات المدربين والإداريين لواقع تطبيق شفافية تقييم الأداء الوظيفي في المعهد تبعًا لاختلاف

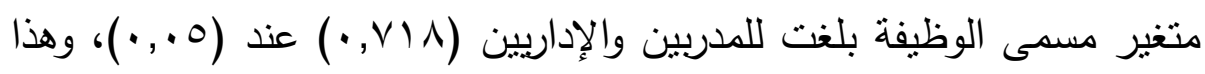

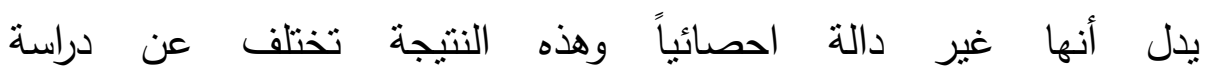
(أبوماضي، • ( ب) والفروق بين المتوسطات راجع لصدفة وتذبذب العينة العشوائية. 
واقع تطبيق شفافية تقييم الأداء الوظيفى من وجهة نظر العاملين بالمعهر الصناعى أ. عبدالمعى المطرفى

جدول (؛ ) مستوى الدلالة للمجموع الكلي لتقديرات المدربين والإداريين

\begin{tabular}{|c|c|c|c|c|c|c|c|}
\hline التعليق & مستوى الدلالة & قيمة ت & الانحراف المعياري & الحستوسبي & العدد & العؤهل & المعيار \\
\hline \multirow{2}{*}{ ر دالة } & \multirow{2}{*}{$\cdot, \vee \wedge \wedge$} & \multirow{2}{*}{$\cdot, \wedge q$} & $7,1 \leq \varepsilon$ & $\leqslant \&, \wedge \neg$ & $r r$ & مدرب & \multirow{2}{*}{ المجموع ككل } \\
\hline & & & 0,19 & $\varepsilon v, \ldots$ & 9 & إداري & \\
\hline
\end{tabular}

يبين الجدول (ع) أن قيم (ت) غير دالة عند مستوى 0 ., • في الدرجة

الكلية لواقع تطبيق شفافية تقييم الأداء الوظيفي في المعهذ تبعًا لاختلاف متغير مسمى الوظيفة، مما يشير إلى عدم وجود فروق ذات دلالة إحصائية بين استجابات عينة البحث لواقع تطبيق شفافية تقييم الأداء الوظيفي في المعهد تبعًا

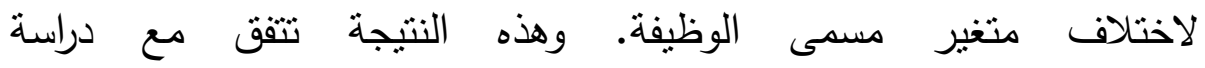

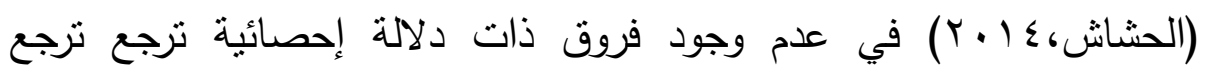
للمسمى الوظيفي.

وجدول (0) يوضح اختبار تحليل التباين الإحادي لدلالة الفروق في استجابات عينة البحث حول واقع تطبيق شفافية تقييم الأداء الوظيفي في المعهد تبعًا لاختلاف متغير عدد سنوات الخبرة.

جدول (•) اختبار تحليل التباين الإحادي لالالة الفروق في استجابات عينة البحث

\begin{tabular}{|c|c|c|c|c|c|c|c|}
\hline التعليق & مستو & فيمة & المربعات & لدرجات & المربعات & التباين & المعيار \\
\hline \multirow{2}{*}{ غيلة } & \multirow{2}{*}{ צוד, } & \multirow{2}{*}{ r } & IN, vor & $r$ & $r v, 0 . \tau$ & المجموعات & \multirow{2}{*}{ الكلية } \\
\hline & & & $r \wedge, .17$ & rq & W.r, & المجموعات & \\
\hline
\end{tabular}

يتضح من الجدول (0) أن قيم (ف) غير دالة عند مستوى 0.,. فأقل

في الدرجة الكلية، مما يشير إلى عدم وجود فروق ذات دلالة إحصائية بين

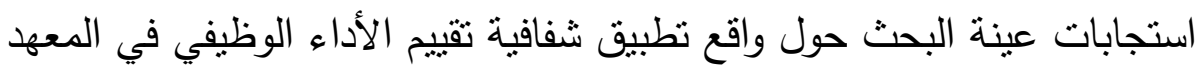


تعود لاختلاف عدد سنوات الخبرة لأفراد العينة وهذه النتيجة تتقق مع دراسة (الحثاش، ع ا • r) في عدم وجود فروق ذات دلالة إحصائية ترجع ترجع لعدد سنوات الخدمة، بينما تختلف عن نتيجة دراسة (أبوماضي، • ( • (ب)، ودراسة (الطراونة والعضايلة، 1 · ( ) التي تؤكد على وجود فروق ذات دلالة إحصائية ترجع ترجع لعدد سنوات الخدمة،. وباستخدام اختبار شفافية لتوضيح مصدر الفروق في استجابات عينة البحث حول واقع تطبيق شفافية تقييم الأداء الوظيفي في المعهد تبعًا لمتغير سنوات الخدمة واستخدامه للكثف عن مصدر نللك الفروق لم يعطي أي نتيجة. 
في ضوء النتائج التي تم التوصل إليها ومناقشتها وتفسيرها في هذه البحث ، فإن البحث نوصي بالتالي:

• ضرورة عمل خطة وبرنامج لتقويم العاملين بشكل دوري (يومي -أسبوعي -

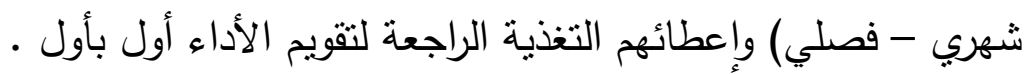
• العمل على التركيز على الأسس والوصف الوظيفي أثناء التقويم للأداء. العمل على توفير قاعدة بيانات متكاملة وشاملة خاصة بكل موظف وشاملة ولاهلة كل نقييماته للأعوام السابقة وكل المهام الموكلة له. الحرص على الموضوعية أثناء تقويم الأداء .

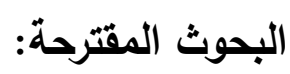

في ضـوء النتائج ومناقتشتها وتفسيرها والتوصيات التي تم التوصل إليها، فإن البحث تقترح التالي: • العلاقة بين تقييم الأداء وتطوير العمل وفاعليته في المعهد من وجهة نظر العاملين فيه.

هفافية تقييم الأداء في مدارس التعليم العام(بنين -بنات) في محافظة بدر . بناء تصور لنشر ثقافة الثفافية في تقييم الأداء والممارسات التنريسية والتدريبية في المؤسسات التعليمية. - توظيف الثقنيات والمستحدثات عند تطبيق الثفافية في تقييم الأداء الوظيفي. إجراء دراسات عن الثفافية الإدارية في مؤسسات الدولة الأخرى نتتاول مجالات أخرى ومجتمعات أخرى. 


\section{المراجع العربية}

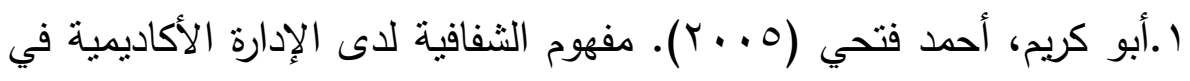

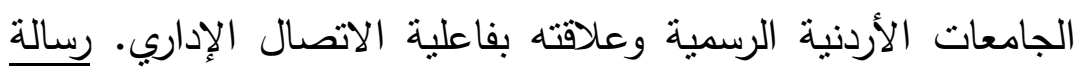
دكتوراه ، الجامعة الأردنية، الأردن.

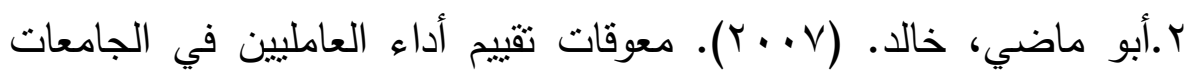
الفلسطينية وسبل علاجها، رسالة ماجستير غير منشورة، الجامعة الإسلامية، غزة.

r.أحمد، أحمد إبراهيم ؛ وأبو الوفا، جمال محمد. (7 1 ب). المضامين التربوية

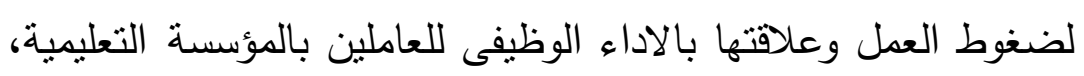

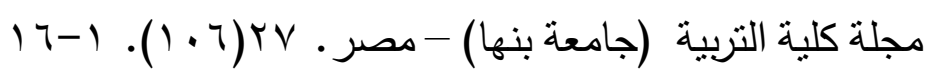

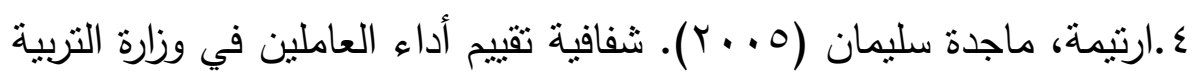

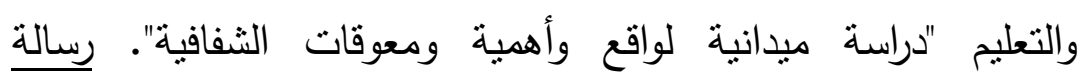
ماجستير، جامعة اليرموك، الأردن.

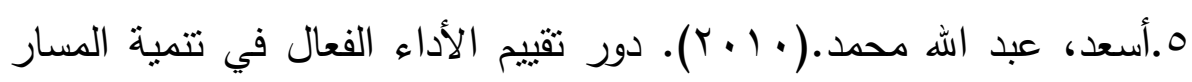
الوظيفي" نموذج مقترح لنظام تقييم الأداء"، اتحاد جمعيات التتمية الإدارية.

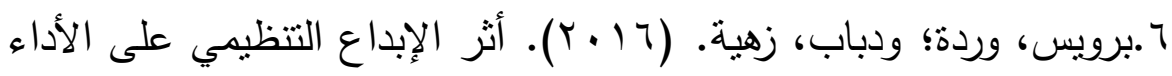

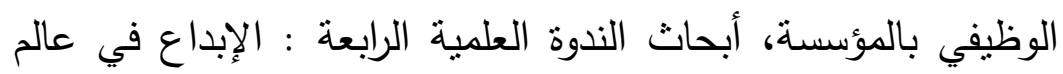
الأعمال - مركز البحث وتطوير الموارد البشرية - رماح - الأردن.

V.الحشاش، خالد سعد برهم. (ع ا • Y). درجة تحقق الثفافية الادارية لدى مديري مديريات التربية و التعليم بمحافظات غزة وعلاقتها بأداء العاملين فيها. رسالة ماجستير، كلية التربية، الجامعة الاسلامية غزة. 
^.الحوامدة، نضال صالح. (ع . . Y). العلاقة بين مستوى إدراك فاعلية وعدالة نظام تقويم الأداء وكل من الأداء الوظيفي والرضا الوظيفي والولاء

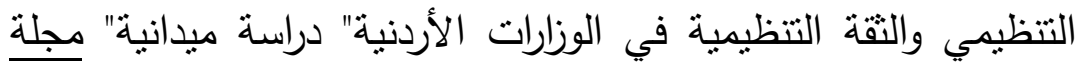
جامعة الملك سعود.

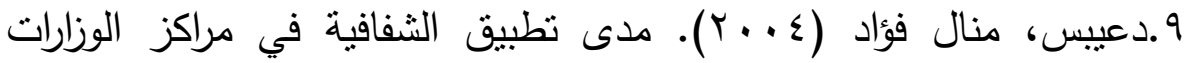

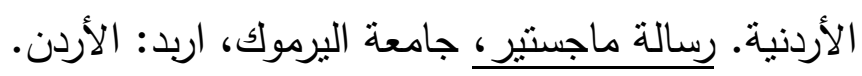

•l.الصحاف، حبيب. (199V) : معجم إدارة الموارد البشرية وشؤون

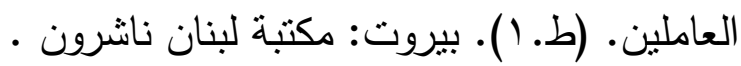

I (الطراونة، رشا نايل حامد؛ العضايلة، علي محمد عمر • (• • ب). أثز تطبيق الثفافية على مستوى المساءلة الإدارية في الوزارات الأردنية،

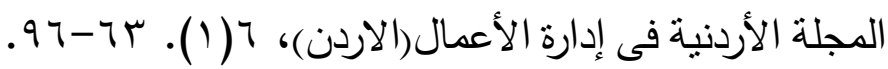
r ( الطشة، غنيم حمود؛ وحوامدة، باسم علي. (9 . . ؟). درجة الالتزام بالثفافية الإدارية في وزارة التربية في دولة الكويت من وجهة نظر العابه العاملين فيها

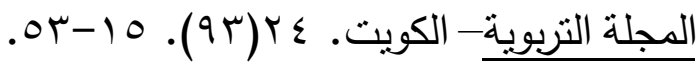

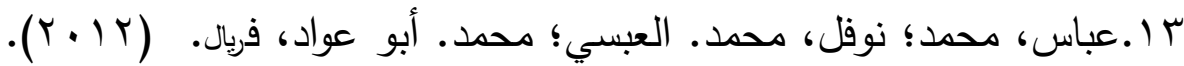
مدخل إلى مناهج البحث في التربية وعلم النفس (طء). دار الميسرة،

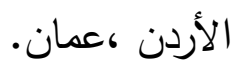

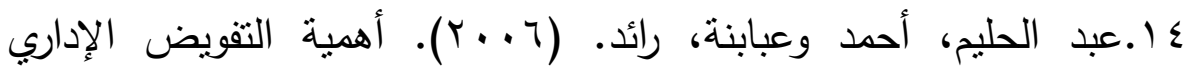
والثفافية في ممارسة الإبداع الإداري في القطاع العام الأردني من

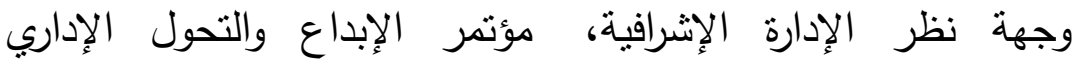

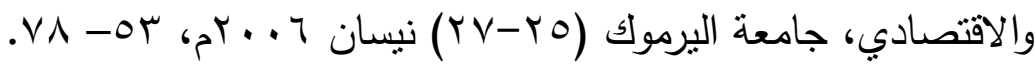

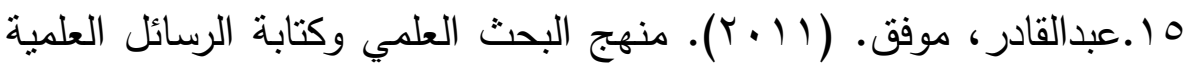

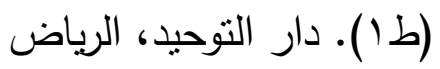




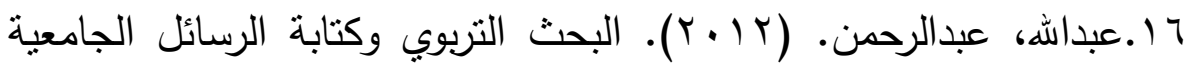

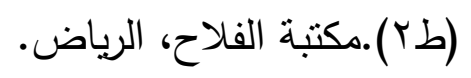

V ا.القرشى، سوزان محمد؛ المالكى، نوال عازب. (7 ( • ب). أثر الانضباط

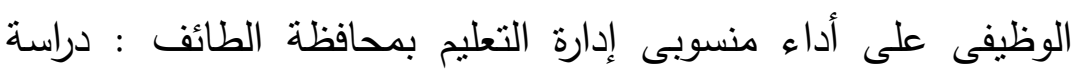

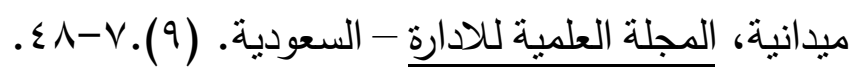

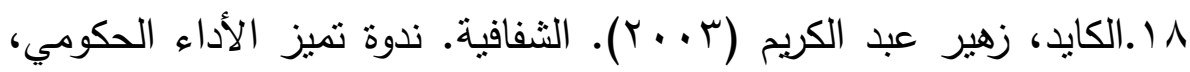

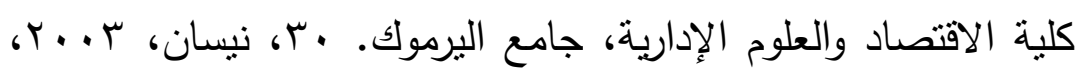

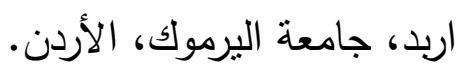

9 (.كرداوي، عادل أحمد محمد. (9 . . ب). النزاهة والثفافية والمسائلة ] المساءلة : [تجارب سودانية، منتدى المائدة المستديرة - الخدمة المدنية ) نحو آفاق جديدة في تقوية النزاهة والثفافية والمساعلة الإدارية. المنظمة

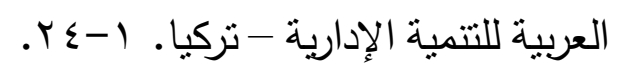

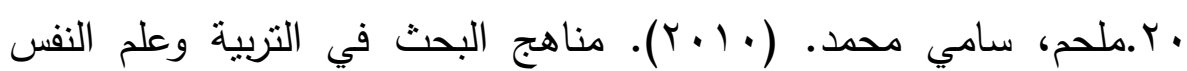

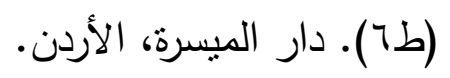

ا . .منصور ، فاطمة عبد الله. (· ( • (Y). تقييم نظام مراقبة جودة الأداء الإداري بالمدارس الثانوية للبنات في ضوء مفهوم الثفافية والمساءلة دراسة ميدانية بمنطقة عسير التعليمية. رسالة ماجستير. كلية التربية للبنات

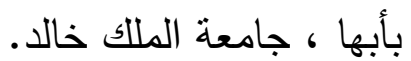

r .اليافعي، شريفة بنت عبداله بن علي. (7 ا ـ Y). نموذج مقترح لتقويم الأداء الوظيفي للمعلم في سلطنة عمان في ضوء بعض النماذج العالمية،

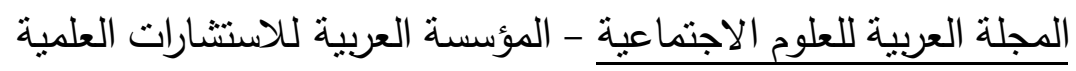

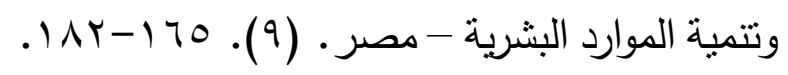


واقع تطبيق شفافية تقييم الأداء الوظيفى من وجهة نظر العاملين بالمعهد الصناعى أ. عبدالمعى المطرفى

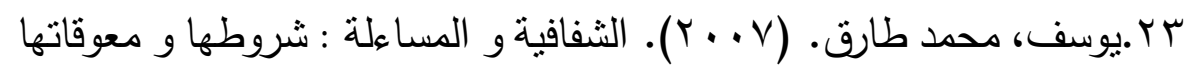

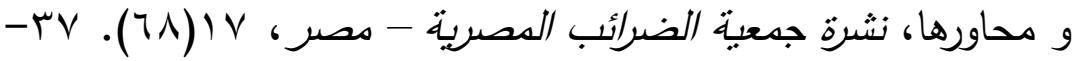

. $\leqslant \leqslant$

ثانباً : المراجيع الأجنيية

1.Grigorescu, V. (2002). Transparency And the Impact of International Organizations on Democratic Consolidation. PhD doctoral dissertation. University of Pittsburgh.

2.Martell, C. R. (2007). Municipal government accountability in brazil. International Journal of Public

Administration، 30(12-14), 1591. 